\title{
John Dewey and the Question of Race: The Fight for Odell Waller
}

\author{
Sam F. Stack, Jr.
}

\begin{abstract}
In an attempt to better understand the complexity of American racism and democracy, this paper explores racism through the plight of an African American sharecropper, Odell Waller, and the reaction and involvement of John Dewey, America's most liberal democratic philosopher of the 20th century. This exploration delves into the nature of American justice in one of the most difficult struggles in our history, the late years of the Depression and the early years of World War II. Furthermore, the paper traces Dewey's limited discussion of race and his involvement in attacking racism in American society.
\end{abstract}

History teaches us that American democratic values can be undermined by racism and prejudice. In an America becoming more culturally diverse, racism and cultural suspicion again cast a shadow over the landscape. While much of the suspicion can be attributed to the September 11 attacks, America has a long history of refusing the poor, people of color, and the culturally diverse the American dream-equality of opportunity. In an attempt to better understand the complexity of American racism and democracy, this paper explores racism through the plight of an African American sharecropper, Odell Waller, and the reaction and involvement of John Dewey, America's most liberal democratic philosopher of the twentieth century. The Waller case provides a context for the exploration of Dewey's thought on race during one of the most difficult struggles in our history, the late years of the Depression and the early years of World War II.

In 1940, Odell Waller was a twenty-three-year-old African American sharecropper living in Gretna, Virginia, a small town in Pittsylvania County. As a share- 
cropper, Waller worked the land for an agreed amount of the crop. In 1940, 60\% of the farms in Pittsylvania County were run by tenants as compared with $27 \%$ for the rest of Virginia. Most sharecroppers owned nothing and were dependent on their landlord to be paid by the share of the crop worked and raised. Waller worked for Oscar Davis, a white man who was also a sharecropper to a larger landowner. In typical fashion, Davis had agreed to pay Waller a portion of the crop worked; however, Davis' landowner had cut his share in 1940 and in turn Davis cut Waller's, leaving Odell only two acres to farm. Since farming two acres was not enough to make it through the winter, Waller left to find work in Maryland, where he sent money back to his family in Gretna. Waller's mother Annie also worked for the Davis family and had even nursed Mrs. Davis during an illness. When Oscar Davis refused to pay Annie Waller for taking care of his wife during her illness, Annie refused to work in Davis' tobacco fields. Davis evicted her. ${ }^{1}$

On a Sunday morning July 16, 1940, Odell Waller was in Gretna visiting his family and discovered that Davis was withholding his family's portion of the crop. Waller borrowed a truck and traveled to the Davis home to pick up his share. Davis refused to pay Waller his share. Both men were armed and an argument ensued. When Davis reached into his pocket, where he often carried a pistol, Waller pulled a handgun and shot Davis four times, mortally wounding him. Fearing that he might be lynched, Waller fled Virginia, moving through several states before being captured in Ohio. He was chased by the local sheriff and his posse of forty armed men as well as by the FBI. The Waller case made national headlines and drew the attention of the Revolutionary Worker's Party, a faction of the Socialist Workers Party and the Workers Defense League (WDL), a civil rights and labor organization. Both organizations fought Waller's extradition to Virginia; however, Waller lost his plea and was extradited to stand trial in Virginia. ${ }^{2}$

In 1940, the Virginia justice system was based on a poll tax, a tax levied for voting eligibility. If you could not pay your poll tax, and most poor whites and African Americans in Virginia could not, you were not placed on the voting rolls. Since juries were pulled from these voting rolls, Odell Waller was not going to be tried by a group of his peers. He was tried by ten white landowners, a carpenter, and a businessman who found him guilty of murder and sentenced him to die in the electric chair. ${ }^{3}$ The Workers Defense League and the NAACP readily took up Waller's cause and saw the case as a means to attack America's economic disparity, racism, and the poll tax and how they in turn corrupted American justice. The WDL, the NAACP team under Thurgood Marshall, the Revolutionary Workers Party, and A. Philip Randolph's Brotherhood of Sleeping Car Porters argued that Waller had been denied due process and was convicted by a jury "more concerned with property rights than with human rights." The WDL wanted the United States Supreme Court to review the case and ultimately outlaw the poll tax. Funds were desperately needed to prepare the case, although most attorneys involved worked without fee. ${ }^{4}$ 
Inequity was characteristic of Pittsylvania County. In this poor rural-tenant farming community, only 200 African Americans out of a voting age population of 19,000 were registered to vote. Only 6,000 whites out of a voting age population of 23,000 were registered. ${ }^{5}$ Educational inequity was also apparent in Jim Crow Pittsylvania County. In 1940, \$23.69 was the annual expenditure per white child in elementary school while the expenditure on African American children was $\$ 10.86$. The gap widened in secondary education with the county spending $\$ 42.06$ for white children to $\$ 15.62$ for African American children. A white high school teacher made $\$ 1,278$ annually while an African American teacher made $\$ 584 .{ }^{6}$ African Americans in Pittsylvania County knew all about separate and unequal.

Although barely literate, Odell Waller had completed three years of high school, but following the death of his uncle, his adoptive father, he had to quit school to work and pay off family debts. He was viewed by whites in the Gretna community as a fair worker, a bootlegger, a black sheep, and a bad-tempered man. Oscar Davis was viewed by the African American community as a bootlegger who was bad tempered, dishonest, prejudiced, and easily frustrated. Davis had a habit of venting his frustrations on those closest around him, which usually included the Waller family. ${ }^{7}$

It was in the search for funds for Waller's defense that John Dewey became aware of the case when African American poet, lawyer, and feminist Pauli Murray wrote him a letter about the case. ${ }^{8}$ On March 28, 1941 Dewey wrote Murray, enclosing a $\$ 5.00$ check for the defense of Waller, and gave permission for the WDL to use his name to appeal for funds. Soon John Dewey and other noted liberals took up the cause of Waller, including Teachers College Professor George Counts, who was deeply involved in the American Labor party and the WDL at the time. One month later, on April 7, 1941, Dewey and others signed a letter to raise funds for Waller through the Workers Defense League. The letter began by comparing Odell Waller to Dred Scott, seeking to contrast the sharecropping system to a form of slavery and attempting to rally forces for abolishing the poll tax. The writers stated, "Ten million Negros and whites - 79\% of the adult citizenry in eight southern statesare shut out from democratic processes by the poll tax." The letter concluded, "We hope you will contribute as generously as you can to help preserve the American principle of equal justice for all."9 That April, Pauli Murray and Annie Waller began a nationwide tour to seek support for Waller's cause. ${ }^{10}$

What drew Dewey to the Waller case? One of America's most prolific scholars and intellectuals of the twentieth century, Dewey had played a role in the founding of the NAACP and the ACLU and had attacked capitalist threats to democracy, but he had written virtually nothing about racism in American society. Dewey biographer Jay Martin describes Dewey's view at the turn of the century: "In 1909, Dewey saw the time had come when racial antagonism and race prejudice might be effectively challenged not so much through legislation as by the operations of voluntary associations." That same year Dewey attended a meeting called by English radical 
William Walling in New York City to discuss the issue of civil and political equality. Industrialist Andrew Carnegie and Booker T. Washington were invited, but both declined the invitation. ${ }^{11}$ Philosopher James Campbell believes Dewey's work was characterized by a "general deadness to America's race problems."12 Shannon Sullivan writes, "We especially need to be wary of our devotion to Dewey when it comes to race. Given Dewey's insistence that philosophy be informed by the context of 'real life,' it is dismaying that Dewey wrote very little about the contradictive role that race and racism play in lived experience." ${ }^{13}$ Yet Dewey's lack of writing on race does not show a lack of interest, but a different conceptualization of the problem. Dewey's actions over time give us a greater understanding of how he was trying to grasp America's complex race problem. An astute observer of political, economic, and social problems, Dewey had trouble understanding its complexity and cultural manifestations, particularly in the south. The Waller case provides a context to better understand this journey.

Dewey had experienced racism first hand. Shortly after the founding of the NAACP, Alice Dewey began to invite African American women to the Dewey home, "in an attempt to join with them and to join them to the women's suffrage movement." When the owner of the building found out, he forbade the Dewey's to hold further integrated meetings. There is no record of Dewey's response to this "unpleasant" incident; however, the NAACP suggested a meeting at the Ethical Culture Meeting House to protest this "infringement of citizens' rights."14

In 1913, working with the National Kindergarten Association, Dewey responded to a request from Dr. P. P. Claxton, then Commissioner of Education of the United States. Claxton had asked for the cooperation of the association to help establish a Kindergarten Division in the Federal Bureau of Education. With Claxton's support, Dewey and the National Kindergarten Association requested funds from the General Education Board for \$10,400 to support a "Colored Demonstration Kindergarten in each of the 13 southern states." Although the request was denied, Dewey believed that there might be some future hope for the project. Dewey believed another grant submission might be successful, since "several persons on the General Education Board are especially interested in Negros and several interested in kindergartens. In closing the letter Dewey estimated the cost for 'colored kindergartens' at $\$ 800.00$ with one teacher and $\$ 1,700.00$ for white kindergartens with two teachers," roughly equivalent in expenditures. ${ }^{15}$

Dewey's trip to Japan and China in 1919 further opened his eyes to racism. He was deeply concerned by the growing aggressive foreign policy of Japan and how the Japanese were using racial discrimination to secure their power and influence in China. Although treated with respect during his trip to Japan, Dewey did not feel the Japanese were interested in his democratic ideals. Historian Robert Westbrook characterized Dewey's feelings: "Japanese society was marked by deep class divisions, held together by the mythology of the emperor cult and the repression of a military state. The free expression of opinion and the scientific analysis of social problems . . . were impossible under these conditions." ${ }^{16}$ While in China, Dewey 
read a paper in 1922, entitled Race Prejudice and Friction, before the Chinese Social and Political Science Association, one of his broadest statements on race. In the paper Dewey referred to racism as a "deep seated and widespread social disease," a prejudice that comes before and blinds us to clear judgment; "it is a desire or emotion which makes us see things in a particular light and gives a slant to all our beliefs." For Dewey, prejudice comes from our habits or incorporated experiences. While prejudice may be due to lack of experiences, Dewey tied it also to our natural aversion to something different or strange to us, "originating probably in the self-protective tendencies of animal life. ... The basis of racial prejudice is instinctive dislike and dread of what is strange." He found that political forces come into play because they can change "race prejudice into racial discrimination," the dominant group seeking "facts to quote in support of their belief in their own superiority." This domination led to what Dewey termed "the most rational factor in the confirming of racial animosities, the economic." Dewey pointed out that when color, tradition, custom, religion, and politics are added to the mix, racial friction is enhanced. He believed that racial prejudice was not the cause of racial friction, but was a product of a "political organization and habits and national rivalries undergirded by economic and industrial differences." While Dewey did seem to understand the social forces behind prejudice, he still gave the greater emphasis to political and economic forces and clearly states so. He emphasized that political and economic forces have the potential to turn race prejudice into outright race discrimination and believed science and psychology had far too often been used to ground racism in absolutes and inherent qualities. His emphasis on these themes continued through the next decade. ${ }^{17}$

In the 1920s Dewey began to show deep concern about the rise of individualism within and fostered by a capitalist economy. Dewey perceived a moral crisis, enhanced by crass materialism and the lack of a central purpose in education and social and political policy. He discussed limits to individual freedom and believed one of the primary goals of education was to train people "for intelligent organization, so that they can unite with each other in a common struggle against poverty, disease, ignorance, credulity and low standards of appreciation and enjoyment."18 However, Dewey did not challenge the difficulty for those that were legally denied it and thus denied equality of opportunity.

In November 1929 Dewey addressed a largely Jewish audience on the subject of Understanding and Prejudice. Reiterating earlier themes, he defined prejudice as "a curious word - one of those happy words in which the instinct of a people expresses itself. It is something that goes before judgment. It is even a kind of foolish and unwise judgment. It is something that precedes judgment that tends to represent and to distort it." For Dewey, prejudice was irrational: an impulse, jealousy, or dislike. ${ }^{19}$ He believed that if we were to understand prejudice, we had to see it beyond the intellectual. "Understanding means something intellectual," he writes, "but it means something that is more than intellectual. We sometimes say comprehension, but comprehension is an inclusive word - it signifies coming together, bring- 
ing things together; and when we say that human beings come to an understanding, we mean to say that they have come to an agreement, that they have reached a common mind, a common outlook from which they see the same things and feel the same way about them. To understand is to stand on common ground." 20 This statement implies that Dewey had the beginning of an understanding of the social forces underlying prejudice; a moral and even emphatic desire to seek dialogue, to listen, and in essence move to democratic community. But did Dewey fully grasp the difficulty on creating this type of community in the Jim Crow South? In $\mathrm{Hu}$ man Nature and Conduct, Dewey wrote, "We are always biased beings, tending in one direction rather than another."21

As a member of the League for Independent Action, Dewey was aware of conditions of racism and poverty in the Jim Crow South. The League for Independent Action was a group of progressive intellectuals committed to the organization of a third political party. At the time of Dewey's involvement, the League included W. E. B. DuBois, Oswald Villard, Norman Thomas, and Reinhold Niebuhr and was modeled on the British Labor Party. In March 1930 the Executive Secretary of the League brought back promising news following a twenty-four day trip in twelve southern states. The Secretary found "some progress, if slow, being made along several lines, in inter-racial relations and justice in the courts for Negroes . . in a more liberal attitude in education for Negroes, in a growing progressivism in the colleges and in some theological seminaries. There is great agricultural depression and a corresponding business depression all through the South, with low wages, great unemployment, vacant stores, etc. All bodes well for a new political rift, with the fact that a single party system having no opposition at all produces corruption; with cities under serviced and over-taxed; with people disgusted over the political leadership." The report was characterized by optimism, in that the current climate boded "well for a new political alignment," and could be dealt with as a "part of the whole economic and social question, rather than as a totally separate problem."22 The report further emphasized that that justice for African Americans could be dealt with best as a part of the whole economic and social picture, rather than as a separate problem. Dewey echoed this optimism in a radio address in October 1931. He argued, "instead of imbuing individuals with the idea that the goal is to sharpen their power so they can get on personally, they must be trained in capacity for intelligent organization so that they can unite with others in a common struggle against poverty, disease, ignorance, credulity, low standards of appreciation and enjoyment. There must be a purpose and methods which will carry over the earlier ideals of political democracy into industry and finance . . . democracy will be a farce unless individuals are trained to think for themselves, to judge independently, to be critical, to be able to detect subtle propaganda and the motive which inspire it. Mass production and uniform regimentation have been growing in the degree in which individual opportunity has waned. The current must be reversed. The motto must be, 'Learn to act with and for others while you learn to think and to judge for yourself.'"23 Still, Dewey's understanding of propaganda 
seems more related to political and economic than social forces, including prejudice. Dewey underestimated, along with other liberals, the educational power of social propaganda that fomented deep prejudice in the Jim Crow South. They also misunderstood that lack of access to the proper education they advocated negated their praxis to critical inquiry and action in the South.

On May 19, 1932, Dewey addressed the twenty-third annual conference of the NAACP in Washington. In perhaps the worst year of the Depression and before New Deal legislation, Dewey directly addressed the African Americans in his audience. "Doubtless you are the first, on the whole to lose employment and the last to be taken on. You are quite likely the last to get an equal opportunity to share in whatever measure of relief or constructive public to work ... but nonetheless, the cause from which all are suffering are the same ... and so the thing that I should like to say to you tonight are the same sort of thing that I would say to representatives of any white group that is also at a disadvantage politically in comparison with the privileged few."24 Dewey went on to attack the two-party system in the United States, arguing that the solution for America's problems could come through a viable third political party. "What is needed," Dewey stated, "is some more fundamental reorganization of political lines, some remedy for conditions that control economic welfare more fundamental than giving a certain number of leaders jobs; and as we know, because of the refusal of the white labor group to go into politics through belief that they can get what they want by distributing their votes between the old parties, they are continually sold out by the political parties." This political organization, Dewey's third party, could attack the competitive order which "has to set man against man, brother against brother, group against group." Dewey ended his speech saying, "Now I will submit to you the thing I would submit to any white group that is also at a disadvantage, since your fundamental difficulties do not come through color or any other one thing. They come from the fact that in a society which is economically and industrially organized as ours is, those who want the greatest profits and those who want the monopoly, power, influence, that money gives, can get it by creating dislike and division among the mass of the people."25 Unfortunately, Dewey neglected the true significance of color in his analysis of the problem. He de-emphasizes what W. E. B. DuBois in 1903 claimed was the problem of the twentieth century, "the color line."26 This was a serious oversight by Dewey.

At the time Dewey addressed the NAACP, The New Republic and The Nation were strongly supporting a third party. Dewey's goal in addressing the conference seems to be to bring the NAACP on board, believing that the two-party system was corrupt and bankrupt. Gary Bullert, in The Politics of John Dewey, notes that Dewey "campaigned energetically through speeches, letters, and articles for an alternative, liberal third party."27 The day following the NAACP speech, The New York Times reported, "Dewey Urges Negroes to Join New Party." The New York Tribune poked fun at Dewey, with "Slump Favors Negro's Status, Dewey Holds."28 One can only wonder what southern African Americans attending the meeting must have thought. Dewey seems to suggest that a change in economics through political change would 
give African Americans equality of opportunity. Most in the south could not vote and Dewey still failed to see the power of tradition, culture, and color deeply embedded in these social forces and their manifestation through racism.

In a speech honoring his eightieth birthday in 1939 and read by Horace Kallen, (Dewey did not attend), Dewey presented some of his clearest ideas about democracy in an address, Creative Democracy-The Task Before Us. ${ }^{29}$

Democracy is a way of life controlled by a working faith in the possibilities of human nature. Belief in the common man is a familiar article in the democratic creed. That belief is without basis and significance save as it means faith in the potentialities of human nature as that nature is exhibited in every human being irrespective of race, color, sex, birth, family, of material or cultural wealth. The faith may be enacted in statutes, but it is only on paper unless it is put in force in the attitude which human beings display to one another in all the incidents and relations of daily life. ${ }^{30}$

By 1939, Dewey was acutely aware of the rise of National Socialism and its attacks on democracy as well as its racist ideology. But he also feared attacks against democracy in this country in the name of protecting national security. As part of the task before us he wrote, "Intolerance, abuse, calling of names because of difference of opinion about religion or politics or business, as well as because of difference of race, color, wealth, or degree of color are treason to the democratic way of life. . . Merely legal guarantees of the civil liberties of belief, free expression, free assembly are of little avail if in daily life freedom of communication, the give and take of ideas, facts, experience is choked by mutual suspicion, not alone but fear and hatred." ${ }^{31}$ Dewey concluded in the address, "Since it is one that can have no end till experience itself comes to an end, the task of democracy is forever that of creation of a freer and more humane experience in which all share and to which all contribute." 32

Did the racist ideology of National Socialism push Dewey to re-examine racism beyond its connection to the means of production or economic forces? Did he now realize that racism in this country extended beyond party affiliation and economics? Perhaps, although there were still problems in his overall assessment. Prior to the war, Dewey had expressed his fear of anti-Semitism in a letter to author Belinda Jelliffe. In a previous letter to Dewey, Jelliffe had expressed an anti-Semitic view that caught Dewey off guard. Dewey responded to her saying, "Your anti-Semitism made by blood run cold-aside from the intrinsic merit of your question - if any-under present circumstances the attitude you express if widely shared is the forerunner of Nazi business and a regime of general hate and distrust. There are all kinds of Jews just as there are all kinds of Yankees, Negroes, Catholics and - probably-Methodists. I can't understand why you should damn the Jews collectively because of the obnoxiousness of some." ${ }^{\text {"3 }}$

Shortly before his involvement with the Waller case, Dewey published an essay, "Contrary to Human Nature," in Frontiers of Democracy. In it, Dewey attacked 
the notion that human nature was fixed, an assumption racists tended to accept and often supported through science and religion. Dewey wrote,

it is often said that human nature is so unalterable by its very constitution that the proposal is bound to fail and therefore shouldn't be tried. It is always dangerous from an intellectual point of view to try to oppose a practical movement with an argument drawn from a purely abstract idea. In the past, changes in institutions, that is in fundamental custom, have been opposed on the ground that they were contrary to Nature in its most universal sense, and hence to the will and reason of God as the Founder of Nature. One has only to go back to the arguments advanced against the abolition of human slavery to see that such was the case."34

Within his sense of pragmatism Dewey was suggesting that habits, traditions, customs, beliefs, and values are not unchangeable. The excuse that God ordained or fixed human nature, that it had always been this or that way, was not good enough. By the onset of World War II, Dewey seemed on the verge of a better understanding of American racism and began to attack it through this pragmatic understanding of experience. He challenged the belief that racism could be grounded in nature and used the experience of women's suffrage to prove his point, that women were not by nature inferior to men.

Odell Waller and Oscar Davis were not all that different economically, both just trying to survive. However, they were clearly distinguished by color in 1940's Virginia society. Dewey fought hard for justice in the Waller case, serving on a citizen's committee that included Bruce Bliven, Harry Emerson Fosdick, Freda Kirchway, and Van Wyck Brooks, among others. The committee supported a rehearing for Waller and petitioned the United States Supreme Court in the 1941 October term. The petition reiterated that Waller had not been tried by a jury of his peers and thus his constitutional rights under the Fourteenth Amendment were denied. The petitioners referenced a previous court case, Smith v. Texas, that stated: "Our notions of what a proper jury is, have developed in harmony without basic concepts of the established tradition in the use of juries as instruments of public justice, that the jury be a body truly representative of the community." 35

While the Waller case was being fought in the courts, the United States entered World War II on December 7, 1941. The Japanese attack on Pearl Harbor spurred fear, suspicion, and racism toward the Japanese community in America. ${ }^{36} \mathrm{On}$ February 19, 1942, President Roosevelt issued an executive order whereby roughly one hundred thousand "aliens and Americans of Japanese origin" were to be evacuated from the west coast and assigned to resettlement camps. Dewey and other liberals, many who were involved with the Waller case, wrote President Roosevelt to express their serious concerns about the evacuation and resettlement. They wrote, "Enforcing this on the Japanese alone approximates the totalitarianism theory of justice practiced by the Nazis in their treatment of the Jews. . . O Our deep desire is for a rescinding of your order which is so at variance with democracy and the Ameri- 
can tradition." Dewey and others believed that the decision to resettle the Japanese was based on public opinion "born in large part of ancient racial prejudices, greed for land the Japanese have developed, and a popular hysteria inflamed by stories of Japanese sabotage and disloyalty in Hawaii." Dewey believed that the evacuation and relocation of the Japanese was a "blow to our democracy and will greatly affect our reputation for racial fair play among the nations of the world." ${ }^{37}$ Racial fair play was a myth. Dewey's appeal failed and the Japanese were relocated. Was Dewey's understanding of the deep-seated racism in American society broadening? Regardless, he remained involved in the Waller case. It was late spring 1942 and the Waller case was now in the hands of the United States Supreme Court.

The Supreme Court refused to review the case and offered no comment on why they refused. Dewey was irate and fired off letters to the Workers Defense League and the New York Times. He wrote, "It is vital to the integrity of our judicial procedure that the Supreme Court either grant the petition for a rehearing or state its reason for refusing." ${ }^{38}$ Dewey believed the refusal of the court to comment only weakened the faith of African Americans and the poor in the democratic process. He noted in his letter the compassion of Virginia Governor Colgate W. Darden, who had granted two reprieves to delay Waller's execution. Dewey clearly wanted Darden to fully commute the death sentence and argued, "The Supreme Court, in failing to state why it refused to review this case, left it unclear whether it regards a jury of poll-tax payers as peers of a man disenfranchised by poverty or whether it considered that because Waller's young trial lawyer raised the commonly known fact that jurors are selected from the tax lists, without adducing specific proof, the condemned man must die solely because of this error." ${ }^{39}$ Dewey had studied the details of the Waller case and knew the case well. He continued his argument in The New York Times the next day, attacking the poll tax and its clear intention to disenfranchise African Americans. According to Dewey, both Oscar Davis and Odell Waller were victims of the oppressive sharecropping system, the former being a "debt ridden renter" and the later a "destitute sharecropper." In closing the letter to the New York Times, Dewey wrote: "And now a word about the social and humanitarian aspects of this case. It is clear from the record that both the slayer and the slain were victims of the economic forces which for some decades have exerted terrible oppression on both white and colored farmers . . caught at the bottom of an American agriculture in the South which gives so little that fighting over it - maybe is not to be taken as an unexpected result. ${ }^{140}$ Dewey still understood the problem to be largely economic as this point.

Dewey petitioned friends, at the request of the WDL, saying that the fight was far from over and that the defense team needed moral and financial support. He wrote, "Your dollars may save Odell Waller's life and will help strengthen democracy on the home front." ${ }^{41}$ In his letter Dewey reiterated the details of the case, particularly the issues of poll tax, but also the fact that the only eyewitness for the prosecution was an African American male at the employ of the Davis family. The young man had testified that Waller had shot Davis in the back after having a friendly 
conversation. Waller claimed self defense. "Once more," Dewey wrote, "our colored citizens already deeply aroused over discrimination against them in the armed forces and defense industries, have been presented with a grievance. ${ }^{142}$ Knowing that time was running out for Waller, Dewey and other liberals petitioned President Roosevelt on June 15, 1942 to appoint a commission of inquiry to investigate the case. "We exercise this sacred right to petition," they wrote, "because the welfare of our beloved country is involved ...." The letter reminded FDR that intervention was not without precedent. Woodrow Wilson had intervened in the case of Tom Mooney. ${ }^{43}$ The petitioners concluded, "We believe it will be a national catastrophe if Waller goes to his death, when millions of his fellow citizens are convinced that he was not tried by a jury of his peers. Your intervention will help restore the badly shaken faith of our Negro minority in American democracy."${ }^{144}$

Stimulated by Dewey's letter to The New York Times, American novelist Pearl Buck wrote, "Odell Waller has ceased to be an individual, he has become a personification of all those to whom democracy is denied in our country." ${ }^{145}$ On June 9 , 1942, ten days before Waller was set for execution, Dewey and others signed a letter for the Workers Defense League to petition Governor Darden. The letter noted the "rising tension of the Negro community which is preparing a dramatic protest blackout of Harlem during the Madison Square Garden mass meeting on the March-on-Washington, June 16 three days before Waller was scheduled to die."46 Waller received a reprieve. Shortly thereafter, Dewey responded to an editorial published on June 20 in The Washington Post stating that Waller was a trouble maker, "a bad man with a bad record." Dewey challenged the writer of the piece, Eugene Isaac Meyer, who owned and published the paper. Dewey argued the evidence was weak for premeditated murder, the only eyewitness being an African American employee of Oscar Davis. ${ }^{47}$

The eyes of the nation were focused on Virginia when Governor Darden granted Waller another reprieve to allow for a commutation hearing. ${ }^{8}{ }^{8}$ The governor had held his hearing on June 29, 1942 but seemed irritated by the outside interest in the case and what he felt interference by the Workers Defense League. In the end, Governor Darden refused to commute the sentence. An observer of the hearing, J. Holmes Smith, wrote, "I believe that the sentence would have been commuted had it not been for the weight of the factors: race prejudice, class interest, and state pride. These are barriers that operate largely unconsciously, but nevertheless really. In a society which is based upon social injustice, the race so treated will naturally believe that it does not get justice in particular instances, even when the state goes through the painstaking process of reviewing the legal case." ${ }^{149}$ On July 2, 1942, the US Supreme Court denied a stay of execution for Waller. The judges included Stone, Black, Jackson, and Frankfurter. Any member of the court had the power to stay an execution. Frankfurter was aware of Dewey's letter to the New York Times and even brought it to the attention of Eleanor Roosevelt. ${ }^{50}$ That same day, twenty-five year old Odell Waller was placed in the electric chair and executed. The International Labor Defense News called the execution "a savage blow against the rights of 
the Negro people, a lynch blow at national unity on the part of internal enemies of equal justice." ${ }^{51}$ A March-on-Washington was held on July 25, 1942 to mourn Waller and protest the poll tax and two recent lynchings. Due to problems of organizing the march, the marchers totaled only around $500 .{ }^{52}$

Waller left a final statement, written in barely legible hand and with numerous misspelled words. He wrote:

I haven't lived so upright and I have asked God to forgive me and I feel he has. ... I accidentally fell and some good people tried to help me... . In my case I worked hard from sun up to sun down trying to make a living for my family and it ended up in death for me. You take big people, as the presidents, governors, judges, their children don't never have to suffer, they has plenty money. Born in a mention [mansion] nothing ever to worry about. I am glad that some people are lucky. The penitentiary all over the United States are full of people ho [who] was pore [poor] tried to work and have something, and couldn't so that maid [made] them steel [steal] and rob." ${ }^{15}$

The Waller case brought to the forefront the deeply embedded inequality and injustice in American society. Dewey was motivated from the early 1930s by political reform that he believed could lead to economic and social reform when he advocated a third party. For Dewey at the time, a third party could help the African Americans overcome their social and economic plight. Yet, it would take much more to fight racism in this country than creating a third party and eliminating the poll tax. Dewey never fully dropped the political and economic solution, removing the poll tax being the first step to giving African Americans and the poor the vote. But this alone could not overcome centuries of racism in the south and American society. Southerners and many northerners had been taught in formal, nonformal, and informal ways that the African American was inferior and segregation de facto and de jure reinforced that assumption. William Paringer argues, in his John Dewey and the Paradox of Liberal Reform, that Dewey was not radical enough in his approach to racism, sexism, poverty, and inequity. ${ }^{54}$ Charlene Siegfried believes Dewey failed to grasp the power behind the oppression of racism and that Dewey took too much from a neo-Marxist analysis, taking an economic inequality approach to the problem of racism. She writes, "he does not, however, pursue the sources of oppression far enough to reflect on why the need to develop and consolidate one's own power is so often understood as requiring denying it to others. And in his conscientious concern with the plight of those who are unjustly treated and strenuous efforts to overcome case after case of specific instances of injustice, he seldom exhibits the anger and angst characteristic of those who practically suffer from bigotry and therefore he does not convey the urgency of the situation." 55 Through his participation in the Waller case, Dewey shows both anger and urgency in what he believes was a travesty of American justice.

He sensed the urgency of the Waller case, but Dewey and other American liberals underestimated what it would take to overcome racial prejudice and op- 
pression. Dewey viewed prejudice as an unconscious judgment or belief. For him, prejudice preceded judgment and too often resulted in irrational thought or acts. Prejudice derives from the Latin praejudicare, to judge before full and sufficient examination, a preconceived judgment or opinion. ${ }^{56}$ For Dewey, education was a process by which one learned to judge through reflection and inquiry, examining the evidence and leading to intelligent action. In the South and other parts of the country, education served to protect the status quo, reinforcing customs and traditions that grounded prejudice and led to racism. An examination of Dewey's thought through the Waller case showed that even in the 1940s he connected prejudice and racism too much to politics and economics and not enough to social forces, the deep seated beliefs that people held that grounded prejudice.

In 1957, five years after Dewey's death, these social forces reared their ugly heads when the school board in Little Rock decided to implement the Brown decision and integrate Little Rock High School. By southern standards, Arkansas was a politically moderate state and no one expected the violence and hostility that occurred there. It set the stage for those who thought violence might keep blacks from integrating schools. ${ }^{57}$ This antagonism to integration was later seen in New Orleans, Birmingham, and even Boston. Racism was deeply embedded in American culture and could not be defeated by just economic or political reform. It took the Civil Rights movement, with its attention to social forces and to morality supported by religious precepts, to finally put dents in the armor of southern racism. ${ }^{58}$ Dewey and other liberals of the era failed to see how deeply racism was embedded in every aspect of Jim Crow society and, it was education, often informal and nonformal, that embedded these cultural mores in southern society that reinforced tradition, living patterns, relationships, and community. However, to see race as an issue of the past and defined only by region misses the point. As Cornel West, who has referred to himself as a prophetic pragmatist in the Deweyan tradition, reminds us, "race still matters." Race coupled with economic disparity continues to plague the quest in our society for true equality of opportunity. ${ }^{59}$

In the late 1940s, Dewey, perhaps influenced by his learning experience in the Waller case, helped "create the American Federation of Negro College Students and persuaded Eleanor Roosevelt to chair its Advisory Council." ${ }^{60}$ On Dewey's ninetieth birthday, Roy Wilkins of the NAACP, who was part of the Waller case, wrote a letter to Dewey. Wilkins noted Dewey's "immeasurable contribution to the struggle against racial discrimination as signer of the Lincoln Day call" which marked the birth of the NAACP. The Lincoln Day call took place on February 12, 1909, the centennial celebration of Lincoln's birthday. The "Call for the Lincoln Emancipation Conference," was written by Oswald Garrison Villard and brought together sixty African American and white leaders, including John Dewey. Wilkins considered Dewey a champion of civil liberties and the rights of man. ${ }^{61}$ Others felt Dewey had made significant contributions to the conception of race in American society. Channing Tobias, noted for his work in the African American YMCA and PhelpsStokes Fund, championed Dewey's contributions. Tobias wrote, "Just as Franz Boas 
rechanneled the thinking of the people of the world on race, so your philosophy has contributed to clearer thinking on how people of different races, classes and cultures may live and work harmoniously and constructively together." ${ }^{12}$ Although Dewey never fully grasped the deep seated sociocultural prejudice of the Jim Crow south, and did not push his own vision of pragmatic inquiry far enough, his philosophy of pragmatism lays down a framework for continuing to reflect, question, imagine, and inquire into the causes and manifestations of racism. At the age of eighty-one in 1940, he continued to attack the political, economic, and social forces that undermined America's democratic values. He understood that fascism did not merely exist in Europe, but threatened the home front not so much militarily, but by our own unquestioned traditions, fears, customs, assumptions, and values about race and ethnicity.

Dewey continued to fight racism even in poor health in the years shortly before his death. A. Philip Randolph, who had worked with Dewey in challenging the Odell Waller decision, wrote to Dewey on November 24, 1950 about Jim Crow in the American military. In the letter he thanked Dewey for his contribution to the committee fighting segregation in the armed forces. Randolph was concerned about the rise of the Dixiecrats and their desire to write segregation into the Draft Act. Perhaps Dewey received some sense of resolution when President Truman signed Order 9981 and 9980 establishing means to eliminate segregation in the military and eliminate discrimination in federal employment. ${ }^{63}$

Educators, politicians, counselors, social workers, and others have a crucial role to play in helping students grasp American racism. Due to economics, most Americans live in segregated communities and go to segregated schools. The case of Odell Waller spoke to one of America's most complex social problems, one that can be better understood through pragmatic inquiry into the historical personal experiences of African Americans and others. The model of pragmatic inquiry can assist in grasping the experience of a growing ethnic and religious diversity in the United States. Neither pragmatic inquiry nor democracy is driven by fear, but by a desire to understand, share, communicate, and to better grasp the basic questions of human existence and interaction. Unfortunately, fear has driven political, social, economic, and educational policy far too often. The Odell Waller case is fundamentally about race, but also about justice and the ability of the public to make informed decisions about ethical issues in a global environment. It is also about education and socialization and how we come to hold beliefs and values that do not foster living in a democratic society and may be antagonistic to it. History teaches us that Odell Waller did not receive the justice he deserved. However, we too often forget the pedagogical nature of history, what it teaches and what we can learn from it. The pragmatic lesson of history is that we learn from our mistakes, our experiences, and make better informed decisions in the future; what Dewey termed as judgment. As Dewey often implied and rightly understood, "creative democracy is always the task before us," to be desire, achieved, and worked for. In a society where segregation and economic disparity appear to be growing and justice 
is far too often related to socioeconomic status, there is a clear indication that the task is far from being completed. ${ }^{64}$

\section{Endnotes}

1. Robert Sherman. The Case of Odell Waller and Virginia Justice, 1940-1942 (Knoxville: University of Tennessee, 1992), 3.

2. The Workers Defense League was founded in 1936 by Norman Thomas and A. Philip Randolph, who at the time of the Waller case was associated with the Brotherhood of Sleeping Car Porters. In 1940 David Clendenin was heading the WDL and Morris Milgram was his assistant. See Pauli Murray, The Autobiography of a Black Activist, Feminist, Lawyer, Priest and Poet (Knoxville: University of Tennessee Press, 1987), 134-35. The WDL took the lead in providing counsel and raising funds for the Waller case. It provided an opportunity to attack the unconstitutionality of the poll tax and that Waller had not been judged by a jury of his peers. Murray also composed an essay, "All for Mr. Davis: The Story of Sharecropper Odell Waller," in a WDL pamphlet The Rights of Man are Worth Defending (New York: League for Adult Education, 1942).

3. "The Headlines Can't Give the Whole Story," Pamphlet from the Worker's Defense League. NAACP Legal File (1940-1950) Reel 31. University of Virginia Library. For a history of the poll tax see Frederic Ogden, The Poll Tax in the South (Tuscaloosa, Alabama: University of Alabama Press, 1958). The jurors in the Waller case were able to pay the $\$ 4.50$ annual poll tax. See also Sherman, The Case of Odell Waller, 4.

4. "The Case of Sharecropper Waller-A Statement of Facts," Pamphlet of the Workers Defense League. NAACP Legal File (1940), 3. See also Thomas H. Sloan to Thurgood Marshall, September 24, 1940, for an early interest by the NAACP in the case.

5. Sherman, The Case of Odell Waller, 4.

6. Ibid. See the Annual Report of the Superintendent of Public Instruction, (Virginia; 1939-1940), 80.

7. Sherman, The Case of Odell Waller, 6-7.

8. John Dewey to Pauli Murray, March 28, 1941, John Dewey Correspondence, 13839. Originally from the files of the Workers Defense League 65/16. See also Pauli Murray to John Dewey. April 1, 1941. John Dewey Correspondence. 13838. Murray writes about her involvement with the Waller case in her autobiography, 150-176. She chronicles her travels in an attempt to raise funds and awareness for the plight of Waller.

9. Lawrence Dennis and William Eaton, George Counts: Educator for a New Age (Carbondale: Southern Illinois University, 1980), 12. See also solicitation letter from the WDL, April 7, 1941, NAACP Legal Defense file, 1941. The solicitation letter from the WDL attacked the disenfranchisement of nearly $80 \%$ of the poor whites and blacks in eight southern states who were not allowed the vote because of the poll tax. Also in the ACLU Archives, vol. 2345, 87. See John Dewey et al. To Whom It May Concern, April 7, 1941, John Dewey Correspondence, (17653), for a copy of the solicitation letter. Alfred Bingham, Paul Kellogg, A. J. Muste, A. Philip Randolph and George Counts were signers of the letter.

10. "Mrs. Waller - Pauli Murray Tour Starts," April 15, 1941, WDL Flyer, NAACP Legal File, 1941.

11. Jay Martin, The Education of John Dewey: A Biography (New York: Columbia University Press, 2002), 247-48. The event was recorded as "White and Blacks Confer as Equals," 
New York Times June 1, 1909, 2. The New York Times article stressed that ". . equal justice should be done to man as man, and particularly the negro, without regard to race or color." In a letter Oswald Villard to Joel Springarn, October 17, 1910, Villard states Dewey's interest in the work of the NAACP, John Dewey Correspondence, (03650). Joel Springarn (1875-1939) was a professor of comparative literature at Columbia University. Villard (1872-1949) was the grandson of William Lloyd Garrison and helped found the NAACP along with Springarn who initiated the Amenia Conference leading to the NAACP.

12. James Campbell, Understanding John Dewey (Chicago: Open Court Press, 1995), 141. Other Dewey scholars Robert Westbrook, Alan Ryan, Richard Bernstein, Larry Hickman, Hans Joas, and even Cornel West do not address Dewey and race satisfactorily in their work. Westbrook claims Dewey played only a minor role in founding the NAACP. John Dewey and American Democracy (Ithaca, New York: Cornell University Press, 1991), 167.

13. Shannon Sullivan, "Reconstruction Zone," in In Dewey's Wake ed. William J. Gavin (Albany: State University of New York Press), 110.

14. Jay Martin, The Education of John Dewey, 248. There is no record of Dewey's response to this incident, although Oswald Garrison Villard reported the incident as "unpleasant" and suggested to Joel Spingarn of the NAACP that a mass protest be held at the Ethical Culture Meeting House. See Oswald Villard to Joel Springarn. February 28, 1911, John Dewey Correspondence, (03651).

15. John Dewey to the National Kindergarten Association Board of Directors, November 8, 1913. See also John Dewey to the National Kindergarten Association, Apri1 11, 1914, John Dewey Correspondence, (08164 and 04876).

16. Robert Westbrook, John Dewey and American Democracy (Ithaca: Cornell University Press, 1991), 241. See also John Dewey to Dewey children, May 13, 1919, John Dewey Correspondence, (10758). Also published as Letters from China and Japan (New York: E.P. Dutton and Company, 1920), 170-81.

17. John Dewey, "Race Prejudice and Friction," MW 13: 243-54. See also Gregory Pappas, "Dewey's Philosophical Approach to Racial Prejudice," Social Theory and Practice 22 (Spring 1996): 47.

18. John Dewey, "American Education, Past and Future," $L W 6$ :97. From a radio address broadcast on October 25, 1931.

19. John Dewey, "Understanding and Prejudice," LW 5: 396-97.

20. Ibid., 396.

21. John Dewey, Human Nature and Conduct, MW 14: 134.

22. Report of the Meeting of the Executive Committee for the League for Independent Political Action, March 7, 1930, John Dewey Correspondence, (13004). For information on the League see Robert Westbrook, John Dewey and American Democracy, 446 and Alan Ryan, John Dewey and the High Tide of American Liberalism (New York: W. W. Norton, 1995), 285-86.

23. Ibid., 97-98.

24. John Dewey, "Address to the National Association for the Advancement of Colored People," LW 6: 224-230. May 19, 1932.

25. John Dewey, LW 6: 228-30.

26. W. E. B. DuBois, The Souls of Black Folk (New York: Knopf, 1903), 5.

27. Gary Bullert, The Politics Of John Dewey (New York: Prometheus, 1983), 147.

28. John Dewey, $L W$ 6: 530. 
29. John Dewey, "Creative Democracy, The Task Before Us," LW 14: 224-30. Initially read as an address by Horace Kallen at a dinner in honor of Dewey, October 20, 1939. Dewey preferred to be with his family during the celebration even though he wrote the address.

30. Ibid., 226.

31. Ibid., 228.

32. Ibid., 230 .

33. John Dewey to Belinda Jelliffe, November 25, 1939, John Dewey Correspondence, (06786). Belinda Dobson Jelliffe (1892-1979) wrote a semi-autobiographical novel For Dear Life (New York: Charles Scribner's Sons, 1936). She was born in Asheville, North Carolina and was friends with southern author Thomas Wolfe.

34. John Dewey, "Contrary to Human Nature," LW 14: 258-59.

35. Smith v Texas, 311 US 128, 130; 61 S. Ct. 164, 165. See also Odell Waller v Rice M. Youell, No. 1097 (October term 1941). This was a motion for leave to file brief as amici curiae in support of petition for a rehearing. NAACP Legal File, 1941.

36. This suspicion had been addressed by Dewey in his article Race Prejudice and Friction, and showed his concerns for the treatment of Asian citizens in the western states.

37. John Dewey et al to Franklin Roosevelt, April 30, 1942, John Dewey Correspondence, (14138). Originally in the Post War Council Records, Box 1, Board of Governor's Minutes, Letters and Responses, 1942-1952. Those who signed the letter included George Counts, Harold Rugg, Clarence Pickett and Reinhold Niebuhr among others. Pauli Murray records in her autobiography the terse response she received from Eleanor Roosevelt upon writing a letter comparing Japanese internment to racial discrimination after the Waller execution. Murray records Eleanor attempted to get FDR to intervene in the Waller case but he refused, believing Governor Darden had acted within his constitutional rights. See Murray, Autobiography, 191-192. This incident is also supported in a letter from Harry Hopkins describing the events. For Hopkins' recollection of the event see Joseph P. Lash, Eleanor and Franklin (New York: W. W. Norton and Company, 1971), 671.

38. John Dewey, Letter to the editor. New York Times, May 18, 1942, 18. Dewey had the support of the editors of The Nation, New Republic, and Common Sense. Supporters included Bruce Bliven, Arthur Garfield hays, Reinhold Niebuhr, and A. Philip Randolph.

39. Parker Rouse, "Only Governor and Federal Courts Can Save Odell Waller," Richmond Times Dispatch, June 7, 1942. National Archives Record Group 48. 1-277, Box 500.

40. John Dewey, Letter to the editor. New York Times, May 19, 1942, 18.

41. John Dewey et al to Workers Defense League Friends, May 15, 1942, John Dewey Correspondence. Original letter in WDL Collection 65/16.

42. John Dewey, Letter to the editor. New York Times May 19, 1942, 18.

43. Tom Mooney was affiliated with radical labor groups such as the International Workers of the World and the WDL. He was arrested after participating in a long, violent strike again the Pacific Gas and Electric Company, but was later acquitted. In 1916, after a bomb explosion in San Francisco, he was arrested, tried, found guilty, and sentenced to hang. Due to perjury of a witness and an international outcry, his sentence was committed to life imprisonment. The Dewey family discussed the incident. See Alice and Jane Dewey to Evelyn Dewey, July 28, 1918, John Dewey Correspondence, (02175).

44. Letter to Franklin D. Roosevelt, June 1942. Petition for a Presidential Inquiry in the Case of Odell Waller. National Archives Record Group 48, E-1-277, Box 500. See also Wil- 
liam M. Agar and Laurence Hosie to John Dewey, June 15, 1942, John Dewey Correspondence, (13832). Agar was a former professor of geology at Yale and Columbia while Hosie was on the board of the WDL and a Presbyterian minister. They were requesting Dewey's support for the letter to FDR and Dewey consented.

45. Pearl Buck, Letter to the editor, New York Times May 30, 1942. Buck mentions Dewey's letter of May 19, 1942. See also "Help Save Odell Waller," Workers Defense League Flyer, National Archives Record Group 48, 1-277, Box 500.

46. John Dewey and others in solicitation letter. "This is a matter of Life or Death." June 9, 1942, NAACP Legal File. Identical flyers are in WDL Collection 65/16 and ACLU Archives, vol. 2427, 190. See also E. J. Prescott to John Dewey, 17 June 1942, John Dewey Correspondence, (09832). Prescott claimed his ancestors worked with the Underground Railroad and wrote to Dewey to voice his support in saving the life of Waller. He also requested a copy of the article Dewey wrote to the New York Times.

47. John Dewey to Eugene Meyer, June 23, 1942, John Dewey Correspondence, Original letter in WDL Collection 187/18.

48. Walter White to Governor Colgate W. Darden, Western Union Telegram. NAACP Legal File, July 1942.

49. J. Holmes Smith, "Some Significant Points in the Waller Case: Hearing Before Governor Darden of Virginia," June 29, 1942, NAACP Legal File.

50. See Sherman, The Case of Odell Waller, 112.

51. "IDL Denounces Waller Execution," International Defense New, July 3, 1942, NAACP Legal File; also see "Urge Roosevelt to Fix Waller's Fate: 600 sign Petition to President to Intervene," New York Times, July 2, 1942, 22. For the Supreme Court denial of petition see Waller v. Youell, Superintendent 316 U.S. 712 (June 1, 1942).

52. Pauli Murray discusses the event and was disturbed that A. Philip Randolph had decided to attend the NAACP convention rather than stay and organize the march. Murray claims the march was the precursor to the 1963 March on Washington led by Martin Luther King. The Supreme Court struck down the Virginia poll tax in 1966. See Pauli Murray, The Autobiography of a Black Activist, 175-76.

53. Odell Waller, "Final Statement," New York Times July 3, 1942, 19.

54. William Paringer, John Dewey and the Paradox of Liberal Reform (New York: SUNY Press, 1983), 19.

55. Charlene Seigfried, "John Dewey's Pragmatist Feminism," in Larry Hickman, Reading John Dewey, (Bloomington: Indiana University Press, 1998), 195-96.

56. See Shannon Sullivan, "Radicalized Habits: Dewey on Race and the Roma," in John Ryder and Emil Visnovsky Pragmatism and Values: the Central European Pragmatist Forum (New York: Rodopi Press, 2004), 139-48.

57. For a history of the Brown case and the history leading up to it see Richard Kluger, Simple Justice (New York: Knopf, 1975). Kluger points out the difficulties in implementing the Brown decision in the Jim Crow south. The Arkansas response is a firm example of the misunderstanding many liberals had of racial prejudice.

58. This view is also supported by Anthony Cook in his book The Least of These: Race, Law and Religion in American Culture (New York: Routledge, 1997), 77-97. Cook argues that the liberal wing of progressivism led by Dewey and others negated the emancipatory and ethical power of religion. Cook emphasizes it was resurrected by Walter Rauschenbusch and Martin Luther King Jr., in the struggle for civil rights. 
59. Cornel West, Race Matters (New York: Vintage Press, 2001).

60. Jay Martin, John Dewey, 248.

61. Ibid. The original letter from Roy Wilkins dated October 19, 1949, is located in the John Dewey Papers. Southern Illinois University Carbondale. Also in John Dewey Correspondence, (11410).

62. Channing Tobias to John Dewey, September 29, 1949, John Dewey Correspondence, (11162).

63. A. Philip Randolph to John Dewey, November 24, 1950, John Dewey Correspondence, (12366). Randolph had led a nonviolent civil rights demonstration at the Democratic Convention in 1948 desiring an anti-Jim Crow platform for the party and equal rights for African Americans. He also helped organize the March on Washington on August 28, 1963 when Martin Luther King gave his "I Have a Dream Speech."

64. John Dewey, "Creative Democracy-The Task before Us," LW 14: 224-30.

Sam F. Stack, Jr. is Professor of Social and Cultural Foundations in the College of Human Resources and Education, West Virginia University.

Email: sstack@mail.wvu.edu 